\title{
Synthesis of Silica-Coated Magnetic Nanoparticles and Application in the Detection of Pathogenic Viruses
}

\author{
Dao Van Quy, ${ }^{1}$ Nguyen Minh Hieu, ${ }^{2}$ Pham Thi Tra, ${ }^{1}$ Nguyen Hoang Nam, \\ Nguyen Hoang Hai, ${ }^{2,3}$ Nguyen Thai Son, ${ }^{4}$ Phan Tuan Nghia, ${ }^{1}$ Nguyen Thi Van Anh, \\ Tran Thi Hong, ${ }^{2}$ and Nguyen Hoang Luong ${ }^{2,3}$
}

\author{
${ }^{1}$ Key Laboratory for Enzyme and Protein Technology, VNU University of Science, 334 Nguyen Trai, \\ Thanh Xuan, Hanoi, Vietnam \\ ${ }^{2}$ VNU University of Science, 334 Nguyen Trai, Thanh Xuan, Hanoi, Vietnam \\ ${ }^{3}$ Nano and Energy Center, Vietnam National University, 334 Nguyen Trai, Thanh Xuan, Hanoi, Vietnam \\ ${ }^{4}$ Hospital 103, 104 Phung Hung, Ha Dong, Hanoi, Vietnam
}

Correspondence should be addressed to Nguyen Hoang Luong; luongnh@vnu.edu.vn

Received 29 March 2013; Revised 6 June 2013; Accepted 10 June 2013

Academic Editor: Subhankar Bedanta

Copyright (C) 2013 Dao Van Quy et al. This is an open access article distributed under the Creative Commons Attribution License, which permits unrestricted use, distribution, and reproduction in any medium, provided the original work is properly cited.

\begin{abstract}
Magnetic $\mathrm{Fe}_{3} \mathrm{O}_{4}$ nanoparticles were prepared by coprecipitation and then coated with silica. These $\mathrm{Fe}_{3} \mathrm{O}_{4} / \mathrm{SiO}_{2}$ nanoparticles consisted of a 10-15 nm magnetic core and a silica shell of 2-5 nm thickness. The superparamagnetic property of the $\mathrm{Fe}_{3} \mathrm{O}_{4} / \mathrm{SiO}_{2}$ particles with the magnetization of $42.5 \mathrm{emu} / \mathrm{g}$ was confirmed by vibrating sample magnetometer (VSM). We further optimized buffers with these $\mathrm{Fe}_{3} \mathrm{O}_{4} / \mathrm{SiO}_{2}$ nanoparticles to isolate genomic DNA of hepatitis virus type $\mathrm{B}$ (HBV) and of Epstein-Barr virus (EBV) for detection of the viruses based on polymerase chain reaction (PCR) amplification of a 434 bp fragment of $S$ gene specific for HBV and $250 \mathrm{bp}$ fragment of nuclear antigen encoding gene specific for EBV. The purification efficiency of DNA of both HBV and EBV using obtained $\mathrm{Fe}_{3} \mathrm{O}_{4} / \mathrm{SiO}_{2}$ nanoparticles was superior to that obtained with commercialized $\mathrm{Fe}_{3} \mathrm{O}_{4} / \mathrm{SiO}_{2}$ microparticles, as indicated by (i) brighter PCR-amplified bands for both HBV and EBV and (ii) higher sensitivity in PCR-based detection of EBV load (copies/mL). The time required for DNA isolation using $\mathrm{Fe}_{3} \mathrm{O}_{4} / \mathrm{SiO}_{2}$ nanoparticles was significantly reduced as the particles were attracted to magnets more quickly (15-20 s) than the commercialized microparticles (2-3 min).
\end{abstract}

\section{Introduction}

Isolation of nucleic acids from clinical samples is an essential step in diagnostics, such as in the detection of pathogenic viruses and bacteria using the polymerase chain reaction (PCR), paternity testing, DNA fingerprinting for crime detection, and DNA sequencing. The nucleic acid isolation method based on interaction with silica, created by Boom et al. in 1990 [1], is currently the most commonly used. Recently, micrometer-size silica-coated magnetic beads have been developed by different groups [2,3] and biotech companies such as Roche Diagnostics, Life Technologies, Beckman Coulter, and Promega to improve the efficiency of purification and save working time because the purification procedures could be performed automatically. This development is very useful for enrichment of nucleic acids in clinical samples with a low copy number of the pathogen, tuberculosis bacterium in sputum, for example, thereby increasing the sensitivity of detection using PCR method [4]. In comparison to the micrometer-size silica-coated magnetic beads, silica-coated magnetic nanoparticles have larger total surface area, thus could be more functional in purification of DNA from samples. However, the synthesis of silicacoated magnetite nanoparticles for specific applications in nucleic acid purification of viruses in blood, which is a very important step in the diagnosis of viruses in specimen, is an emerging area. We therefore present a method for synthesizing the $\mathrm{SiO}_{2}$-coated $\mathrm{Fe}_{3} \mathrm{O}_{4}$ magnetic nanoparticles and use the particles in the isolation of DNA of Hepatitis virus type B (HBV) and Epstein-Barr virus (EBV) from several real 
serum samples. These viruses are commonly found in blood infection and the cause of hepatitis $(\mathrm{HBV})$ and particular cancers and lymphomas (EBV) [4, 5].

\section{Materials and Methods}

2.1. Synthesis of Silica-Coated Magnetic Nanoparticles. Magnetic $\mathrm{Fe}_{3} \mathrm{O}_{4}$ nanoparticles were synthesized by using coprecipitation from iron (III) chloride and iron (II) chloride solutions with the assistance of aqueous ammonia solution as described elsewhere [6]. The synthesized magnetic nanoparticles were washed several times with alcohol and then distilled water until $\mathrm{pH}$ 7.0. $\mathrm{Fe}_{3} \mathrm{O}_{4} / \mathrm{SiO}_{2}$ nanoparticles were prepared by coating magnetic nanoparticles with silica. $100 \mathrm{~mL}$ of the suspension of prepared magnetic nanoparticles (containing $1 \mathrm{~g}$ magnetite) was stored in a flask. $50 \mathrm{~mL}$ of the $10 \%$ solution of aqueous tetraethylorthosilicate (TEOS) was added to the flask together with $70 \mathrm{~mL}$ alcohol and mixed using an overhead stirrer. The $\mathrm{pH}$ of the suspension was adjusted to 9.0 with $\mathrm{NaOH}$. The flask was then heated to $90^{\circ} \mathrm{C}$ and stirred at this temperature for $6 \mathrm{~h}$. After cooling to room temperature (RT), the suspension was washed twice with alcohol and six times with distilled water. The final suspension volume was adjusted to $100 \mathrm{~mL}$ with water.

$\mathrm{Fe}_{3} \mathrm{O}_{4} / \mathrm{SiO}_{2}$ nanoparticles were characterized using a transmission electron microscope (TEM JEM1010, JEOL) and Fourier-transform infrared (FTIR) spectroscopy (FT/IR6300, JASCO). Magnetic curves were measured using a DMS880 vibrating sample magnetometer (VSM) at RT.

For further experiments in nucleic acid isolation, $\mathrm{Fe}_{3} \mathrm{O}_{4} / \mathrm{SiO}_{2}$ nanoparticles were stored in $100 \mathrm{mM}$ Tris- $\mathrm{HCl}$ buffer ( $\mathrm{pH}$ 7.0). For each DNA isolation reaction from $200 \mu \mathrm{L}$ serum sample, $50 \mu \mathrm{L}$ of $\mathrm{Fe}_{3} \mathrm{O}_{4} / \mathrm{SiO}_{2}$ nanoparticles at a concentration of $25 \mathrm{mg} / \mathrm{mL}$ was used.

2.2. Preparation of DNA Isolation Buffers. A set of nucleic acid buffers were made based on the method described previously by Boom et al. [1] and optimized in this work suitably for properties of $\mathrm{Fe}_{3} \mathrm{O}_{4} / \mathrm{SiO}_{2}$ nanoparticles. The set contained (i) Proteinase $\mathrm{K} 20 \mathrm{mg} / \mathrm{mL}$ (BioBasic), (ii) lysis buffer (LB: $30 \mathrm{mM}$ Tris- $\mathrm{HCl} \mathrm{pH}$ 7.0, $1 \mathrm{M} \mathrm{NaCl}, 4.5 \mathrm{M}$ GuSCN, $20 \mathrm{mM}$ EDTA, 1.5\% Triton X-100), (iii) two types of washing buffers (WB1: 30 mM Tris-HCl, pH 7.0, 2.25 M GuSCN, 56\% ethanol; WB2: $10 \mathrm{mM}$ Tris- $\mathrm{HCl} \mathrm{pH}$ 7.0, 70\% ethanol), and (iv) elution buffer (EB: 10 mM Tris-HCl pH 8.5, 1 mM EDTA).

2.3. Primer Design and Cloning of Plasmids Harbouring Specific Genes for HBV and EBV as Standards for PCR. The primers for HBV (HBSF: $5^{\prime}$-CTTTCATCCTGCTGCTATGCCT; HBSR: $5^{\prime}$-AGGGTTCAAATGTATACCCAAAGACA-3') were designed based on previous work by Abe et al. [7] and Nghia et al. [8], for the amplification of a $434 \mathrm{bp}$ specific fragment of $S$ gene for HBV. Sets of primers for nested PCR to detect EBV (EBVexF: 5' -TGGAAACCCGTCACTCTC3'; EBVexR: 5'-AATGGCATAGGTGGAATG-3'; EBVinF: TGTTGGAAACCCGTCACTCTC-3'; EBVinR: $5^{\prime}$-GGGTAATGGCATAGGTGGAATG- $3^{\prime}$ ) were designed based on the modification of previous primer design studies by van Baarle et al. [5], which was based on the conserved sequence of genes encoding the nuclear antigens EBNA-2 that generated a DNA product of $250 \mathrm{bp}$ (named as EBV250). The PCR primers (EBVF3: $5^{\prime}$-GGAACCTGGTCATCCTTGC-3'; EBFR3: $5^{\prime}$-ACGTGCATGGACCGGTTAAT-3'; EBV Taqman probe: $5^{\prime}$-(FAM)-CGCAGGCACTCGTACTGCTCGCT-(TAMRA)- $3^{\prime}$ ) for real-time PCR using TaqMan probe (Roche Diagnostics) to measure EBV virus load were designed previously [9] based on the sequence encoding nonglycosylated membrane protein BNRF1 p143 and generating a PCR product of $74 \mathrm{bp}$ named as EBV-74. The $434 \mathrm{bp}$ for HBV and $250 \mathrm{bp}$ and $74 \mathrm{bp}$ for EBV were cloned into pGEM-T/A plasmid (Promega). The plasmids harbouring the specific 434 bp bands for HBV were named as pGEM-HBV. The ones harbouring the specific $250 \mathrm{bp}$ and 74 bands for EBV were named as pGEM-EBV-250 and pGEMEBV-74, respectively. The cloned plasmids were then purified and used as a template for sequencing their specific inserted genes for HBV (HBV-434) and EBV (EBV-250, EBV-74). The sequences were compared for homology to the abovementioned standard genes for HBV and EBV (as posted on the international gene bank). The plasmids were diluted into 10 -fold serial concentrations ranging from $4 \times 10^{9}$ to $4 \times 10^{2}$ copies/mL.

2.4. Recovery of Standard DNA Plasmid and Isolation of Genomic DNA of Viruses from Serum. HBV and EBV negative and positive serum samples were collected at the National Hospital of Tropical Diseases, Hospital 103, and Bach Mai Hospital, Vietnam. Either standard DNA plasmids pGEMHBV, pGEM-EBV-250, and pGEM-EBV-74 or serum samples containing $\mathrm{HBV}$ and $\mathrm{EBV}$ were recovered or purified using obtained $\mathrm{Fe}_{3} \mathrm{O}_{4} / \mathrm{SiO}_{2}$ nanoparticles and the optimized buffers in this work. Silica-coated $\mathrm{Fe}_{3} \mathrm{O}_{4} / \mathrm{SiO}_{2}$ microparticles named Dynabeads Myone Silane (Life Technologies) were used as controls for our $\mathrm{Fe}_{3} \mathrm{O}_{4} / \mathrm{SiO}_{2}$ nanoparticles. The protocol for isolating DNA of the virus from multi-serum samples was set up using special 96-well ELISA plastic plates (Thermo Scientific, code 5530100) and MagnaBot 96 Magnetic Separation (Promega), which included four steps. (i) Lysis to release virus genomic DNA: $20 \mu \mathrm{L}$ proteinase $\mathrm{K}(10 \mathrm{mg} / \mathrm{mL})$ and $300 \mu \mathrm{L}$ LB were added into $200 \mu \mathrm{L}$ of serum sample. The solution was mixed well by pipetting 3-5 times before incubating at RT for $10 \mathrm{~min}$. (ii) Binding of the released DNA onto $\mathrm{Fe}_{3} \mathrm{O}_{4} / \mathrm{SiO}_{2}$ nanoparticles in LB. Next, $50 \mu \mathrm{L}$ of $\mathrm{Fe}_{3} \mathrm{O}_{4} / \mathrm{SiO}_{2}$ nanoparticles and $150 \mu \mathrm{L}$ isopropanol were added to the LBtreated serum. The mixture was incubated for $3 \mathrm{~min}$ at RT for binding of DNA onto the $\mathrm{Fe}_{3} \mathrm{O}_{4} / \mathrm{SiO}_{2}$ nanoparticles. Then MagnaBot 96 Magnetic Separation (Promega) was applied for $30 \mathrm{~s}$ to attract $\mathrm{Fe}_{3} \mathrm{O}_{4} / \mathrm{SiO}_{2}$ nanoparticles bound with DNA and for $3 \mathrm{~min}$ to attract Dynabeads Myone Silane bound with DNA or until the solution was clear/white. Next, the clear solution was removed. (iii) Washing off contaminated non-DNA biomolecules using WB1 and WB2: MagnaBot 96 was switched off and WB1 was added into the wells containing $\mathrm{Fe}_{3} \mathrm{O}_{4} / \mathrm{SiO}_{2}$ nanoparticles, followed by mixing well the suspension pipetting 5 times. Then MagnaBot 96 was applied again for attracting $\mathrm{Fe}_{3} \mathrm{O}_{4} / \mathrm{SiO}_{2}$ nanoparticles, 


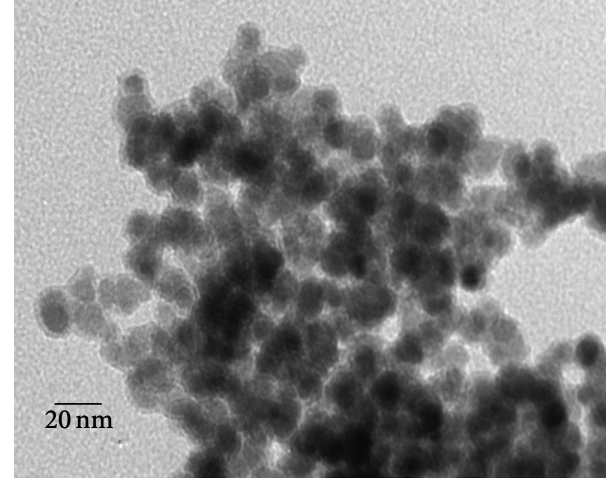

Figure 1: TEM image of $\mathrm{Fe}_{3} \mathrm{O}_{4} / \mathrm{SiO}_{2}$ nanoparticles.

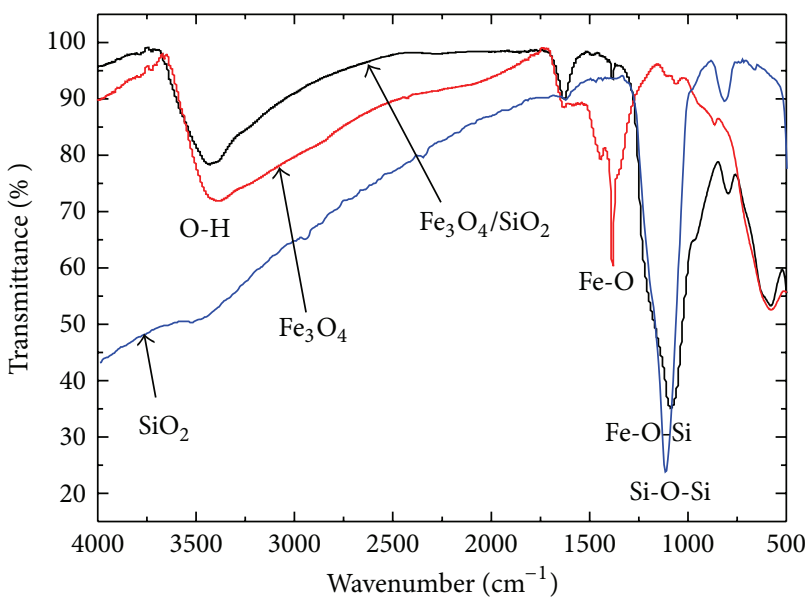

FIgURE 2: FTIR spectra of $\mathrm{SiO}_{2}, \mathrm{Fe}_{3} \mathrm{O}_{4}$, and $\mathrm{Fe}_{3} \mathrm{O}_{4} / \mathrm{SiO}_{2}$ nanoparticles.

allowing removal of the washing solution. This step was repeated with WB2. In this case, WB2 must be completely removed and residual ethanol evaporated by air drying. (iv) Elution using EB: MagnaBot 96 was switched off and $100 \mu \mathrm{L}$ EB was added in to each well for mixing by pipetting 5 times. The suspension was incubated at $65^{\circ} \mathrm{C}$ for $3 \mathrm{~min}$. The solution containing DNA was eluted after applying MagnaBot 96 to attract the nanoparticles. For recovery of standard DNA plasmids, the same protocol was intentionally applied. Isolated DNA concentration was measured and calculated by absorbance at $260 \mathrm{~nm}$ using a NanoDrop spectrophotometer (Thermo Scientific). The samples were used immediately or stored at $-80^{\circ} \mathrm{C}$ for PCR detection of specific DNA bands for $\mathrm{EBV}$ and $\mathrm{HBV}$.

2.5. Polymerase Chain Reaction to Detect $H B V$ and EBV. Purified DNA of HBV from serum samples were used as a template for PCR detection of HBV, as described by Nghia et al. [8]. Amplification of $250 \mathrm{bp}$ specific fragments for EBV was optimized in this work under 35 cycles of the following conditions: $94^{\circ} \mathrm{C}$ for $30 \mathrm{~s}, 52^{\circ} \mathrm{C}$ (initial 5 cycles) and $56^{\circ} \mathrm{C}$ (following 25 cycles) for $45 \mathrm{~s}$, and $72^{\circ} \mathrm{C}$ for $60 \mathrm{~s}$. Real-time PCR to quantitatively measure the EBV virus

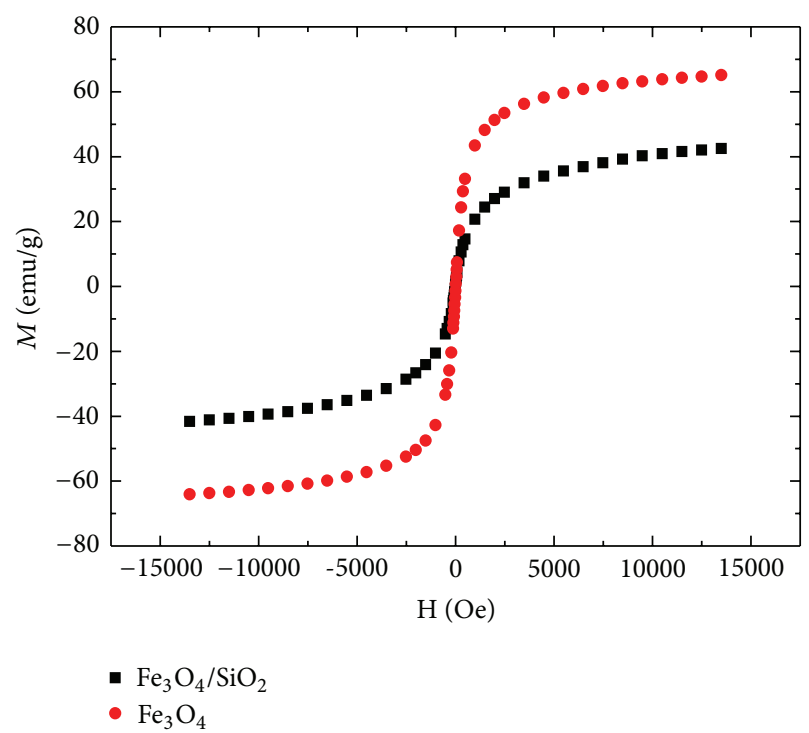

Figure 3: Magnetization curves of $\mathrm{Fe}_{3} \mathrm{O}_{4}$ and $\mathrm{Fe}_{3} \mathrm{O}_{4} / \mathrm{SiO}_{2}$ at room temperature.

load through amplification of $74 \mathrm{bp}$ specific for EBV was performed following Niesters et al. [9] using 45 cycles of the following conditions: $95^{\circ} \mathrm{C}$ for $15 \mathrm{~s}$ and $60^{\circ} \mathrm{C}$ for $1 \mathrm{~min}$.

\section{Results and Discussion}

3.1. Properties of Silica-Coated Magnetic Nanoparticles. Figure 1 shows the TEM image of $\mathrm{Fe}_{3} \mathrm{O}_{4} / \mathrm{SiO}_{2}$ nanoparticles. From this image it can be seen that $\mathrm{Fe}_{3} \mathrm{O}_{4} / \mathrm{SiO}_{2}$ nanoparticles were formed by $10-15 \mathrm{~nm}$ diameter of seed and the surrounding layer has a thickness of about $2-5 \mathrm{~nm}$. Figure 2 shows the FTIR spectra of prepared $\mathrm{Fe}_{3} \mathrm{O}_{4}, \mathrm{Fe}_{3} \mathrm{O}_{4} / \mathrm{SiO}_{2}$ nanoparticles and $\mathrm{SiO}_{2}$ for comparison. In all spectra, the absorption bands at $3650 \div 3200 \mathrm{~cm}^{-1}$ correspond to $\mathrm{O}-\mathrm{H}$ stretching mode. The spectra of $\mathrm{Fe}_{3} \mathrm{O}_{4}$ and $\mathrm{Fe}_{3} \mathrm{O}_{4} / \mathrm{SiO}_{2}$ show the absorption bands near $500 \mathrm{~cm}^{-1}$ which are assigned to $\mathrm{Fe}-\mathrm{O}$ stretching mode. The spectrum of $\mathrm{SiO}_{2}$ shows the $\mathrm{Si}-\mathrm{O}-\mathrm{Si}$ stretching vibration at $1070 \div 1080 \mathrm{~cm}^{-1}$. The spectrum of $\mathrm{Fe}_{3} \mathrm{O}_{4}$ shows an absorption at around $1390 \mathrm{~cm}^{-1}$ which is assigned to $\mathrm{Fe}-\mathrm{O}$ stretching mode. This absorption also appears in the spectrum of $\mathrm{Fe}_{3} \mathrm{O}_{4} / \mathrm{SiO}_{2}$ but with smaller intensity. This can be explained by the covering of $\mathrm{SiO}_{2}$ layers. The existence of $\mathrm{SiO}_{2}$ layers in the spectrum of $\mathrm{Fe}_{3} \mathrm{O}_{4} / \mathrm{SiO}_{2}$ can be seen by the $\mathrm{Si}-\mathrm{O}-\mathrm{Si}$ stretching vibration at $1070 \div 1080 \mathrm{~cm}^{-1}$ as well as the $\mathrm{Fe}-\mathrm{O}-\mathrm{Si}$ stretching vibration at $1050 \div 1250 \mathrm{~cm}^{-1}$. The data strongly suggest that the $\mathrm{Fe}_{3} \mathrm{O}_{4}$ nanoparticles were successfully coated with $\mathrm{SiO}_{2}$ layers. The FTIR results can be used for confirming the silica coating on nanoparticles as recently discussed by Luong et al. [10] on $\mathrm{SiO}_{2}$-coated $\mathrm{FePt}$ nanoparticles.

Figure 3 shows the magnetic curves of $\mathrm{Fe}_{3} \mathrm{O}_{4}$ and $\mathrm{Fe}_{3} \mathrm{O}_{4} / \mathrm{SiO}_{2}$ nanoparticles measured at room temperature. Both of them show superparamagnetic property (i.e., no remanence effect) with high saturation magnetization of 
TABLE 1: Quantitation of EBV load in serum using DNA templates purified by $\mathrm{Fe}_{3} \mathrm{O}_{4} / \mathrm{SiO}_{2}$ nanoparticles and Dynabeads.

\begin{tabular}{lccc}
\hline Sample number & Material for DNA isolation & $C_{t}$ (threshold cycle) & Virus load (copies/mL) \\
\hline \multirow{2}{*}{7} & $\mathrm{Fe}_{3} \mathrm{O}_{4} / \mathrm{SiO}_{2}$ nanoparticles & 36.2 & $7.17 \times 10^{3}$ \\
& Dynabeads & 40.62 & $6.53 \times 10^{2}$ \\
\hline \multirow{2}{*}{10} & $\mathrm{Fe}_{3} \mathrm{O}_{4} / \mathrm{SiO}_{2}$ nanoparticles & 26.78 & $1.18 \times 10^{6}$ \\
& Dynabeads & 27.73 & $7.04 \times 10^{5}$ \\
\hline
\end{tabular}

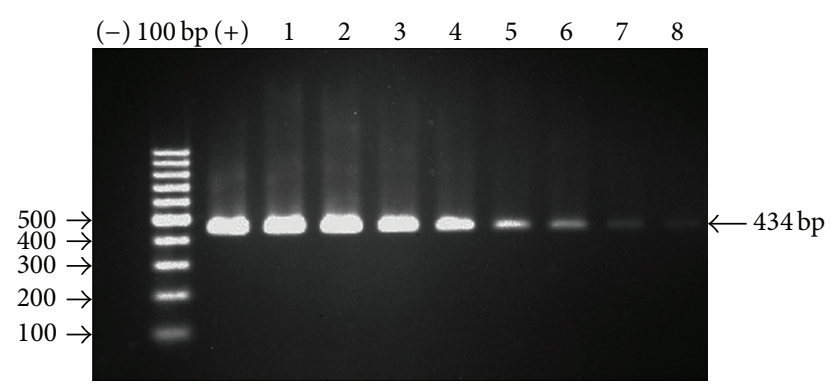

FIGURE 4: Electrophoresis result of PCR products of HBV specific gene using recovered DNA plasmids pGEM-HBV as templates. (-) negative control, $100 \mathrm{bp}$ DNA ladder, $(+)$ positive control: PCR product of purified pGEM-HBV, lane 1-8: PCR products using DNA plasmids after recovering by $\mathrm{Fe}_{3} \mathrm{O}_{4} / \mathrm{SiO}_{2}$ nanoparticles at tenfold diluted initial DNA concentrations, ranging from $4 \times 10^{9}$ copies $/ \mathrm{mL}$ (lane 1) to $4 \times 10^{2}$ copies $/ \mathrm{mL}$ (lane 8 ).

$42.5 \mathrm{emu} / \mathrm{g}$ and $65.1 \mathrm{emu} / \mathrm{g}$ for $\mathrm{Fe}_{3} \mathrm{O}_{4} / \mathrm{SiO}_{2}$ and $\mathrm{Fe}_{3} \mathrm{O}_{4}$ samples, respectively. The $\mathrm{Fe}_{3} \mathrm{O}_{4} / \mathrm{SiO}_{2}$ sample had a smaller magnetization because the magnetic nanoparticles were coated with nonmagnetic layers of $\mathrm{SiO}_{2}$. From the above values of magnetization, the average thickness of the $\mathrm{SiO}_{2}$ layers can be estimated to be $1-1.5 \mathrm{~nm}$, in good agreement with that obtained from TEM measurements.

\subsection{Purification of DNA of Hepatitis Virus Type B (HBV)} Using Silica-Coated Magnetic Nanoparticles and Optimized Buffers. Before testing the DNA purification procedure with real serum samples, we measured the efficiency of DNA recovery of the $\mathrm{Fe}_{3} \mathrm{O}_{4} / \mathrm{SiO}_{2}$ nanoparticles and the optimized buffers using standard pure pGEM-HBV plasmid at 10fold diluted concentrations ranging from $4 \times 10^{9}$ copies $/ \mathrm{mL}$ to $4 \times 10^{2}$ copies $/ \mathrm{mL}$. The enriched DNA solutions were used as templates for amplification of $434 \mathrm{bp}$ fragment of $S$ gene specific for HBV. As shown in Figure 4, from left to right, we could detect bands of about $434 \mathrm{bp}$ with reducing intensities proportional to reducing concentrations from 4 $\times 10^{9}$ copies $/ \mathrm{mL}$ to $4 \times 10^{2}$ copies $/ \mathrm{mL}$ (Figure 4 , lane 18). This result indicates that $\mathrm{Fe}_{3} \mathrm{O}_{4} / \mathrm{SiO}_{2}$ nanoparticles and the optimized buffer could successfully enrich DNA from solution and that the purified DNA was qualified for further PCR-based detection of $\mathrm{HBV}$ at a sensitivity of $4 \times 10^{2}$ copies/mL.

We then used $\mathrm{Fe}_{3} \mathrm{O}_{4} / \mathrm{SiO}_{2}$ nanoparticles and the buffers to isolate DNA of $\mathrm{HBV}$ in six real serum samples (one negative Figure 5 lane 5 and five positives Figure 5 lane 1-4, 6). As a result, we could observe faint specific bands of $434 \mathrm{bp}$ for $\mathrm{HBV}$ in samples in lanes 1 and 3, and very bright bands of

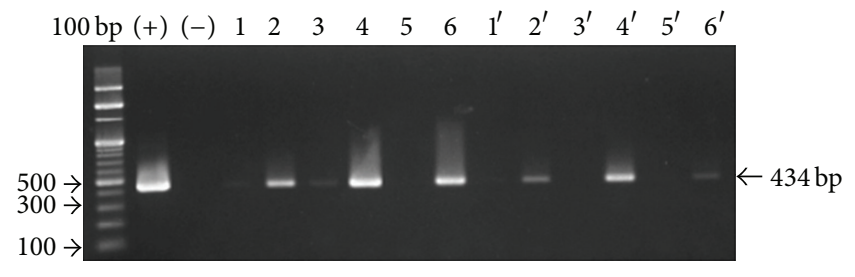

FIGURE 5: Electrophoresis result of PCR products of HBV specific gene using DNA purified by $\mathrm{Fe}_{3} \mathrm{O}_{4} / \mathrm{SiO}_{2}$ nanoparticles: 100 bp DNA ladder, (+) positive control: PCR product of purified pGEM-HBV, (-) negative control, lanes 1 to 6 : PCR products using purified DNA from samples from number 1 to 6 by $\mathrm{Fe}_{3} \mathrm{O}_{4} / \mathrm{SiO}_{2}$ nanoparticles, lane $1^{\prime}$ to $6^{\prime}$ : PCR products using purified DNA from samples from number 1 to 6 by Dynabeads.

$434 \mathrm{bp}$ for HBV in samples in lanes 2, 4, and 6. Meanwhile, no band was observed in the sample in lane 5 . The data indicates that six real serum samples had different concentrations of virus copies, of which the sample in lane 6 had the highest virus load. Our data were in good agreement with those confirmed by the hospital where the samples were collected. In parallel, we performed similar experiments with these six serum samples using the commercialized silica-coated magnetic microparticles Dynabeads Myone Silane (short name: Dynabeads, Life Technologies). As shown in Figure 5, clear bands of $434 \mathrm{bp}$ for HBV were observed in the samples in lane $2^{\prime}, 4^{\prime}$, and $6^{\prime}$. However, intensities of those bands were weaker compared to those in the same samples in lanes 2, 4, and 6 obtained in the case of $\mathrm{Fe}_{3} \mathrm{O}_{4} / \mathrm{SiO}_{2}$ nanoparticles. We could not observe the specific PCR-amplified bands in the samples in lanes $1^{\prime}$ and $3^{\prime}$, possibly due to the low levels of purified template DNA obtained when using Dynabeads. We conclude then that $\mathrm{Fe}_{3} \mathrm{O}_{4} / \mathrm{SiO}_{2}$ nanoparticles may be more efficient than Dynabeads in DNA isolation of $\mathrm{HBV}$ from serum.

3.3. Purification of DNA of Epstein-Barr Viruses (EBV) Using Silica-Coated Magnetic Nanoparticles and Optimized Buffers. $\mathrm{Fe}_{3} \mathrm{O}_{4} / \mathrm{SiO}_{2}$ nanoparticles and the buffers were then used to isolate DNA of EBV in real serum samples, in comparison to Dynabeads. Among 10 suspected EBV infected serum samples, we could detect clearly $250 \mathrm{bp}$ specific bands for EBV in the samples 7 and 10 using both $\mathrm{Fe}_{3} \mathrm{O}_{4} / \mathrm{SiO}_{2}$ nanoparticles (Figure 6(a), lanes 7 and 10) and Dynabeads (Figure 6(b), lanes $7^{\prime}$ and $\left.10^{\prime}\right)$. However, the brighter signals were observed when using $\mathrm{Fe}_{3} \mathrm{O}_{4} / \mathrm{SiO}_{2}$ nanoparticles, indicating that the DNA isolation efficiency of EBV by $\mathrm{Fe}_{3} \mathrm{O}_{4} / \mathrm{SiO}_{2}$ nanoparticles was higher than that using Dynabeads. Further, real-time 


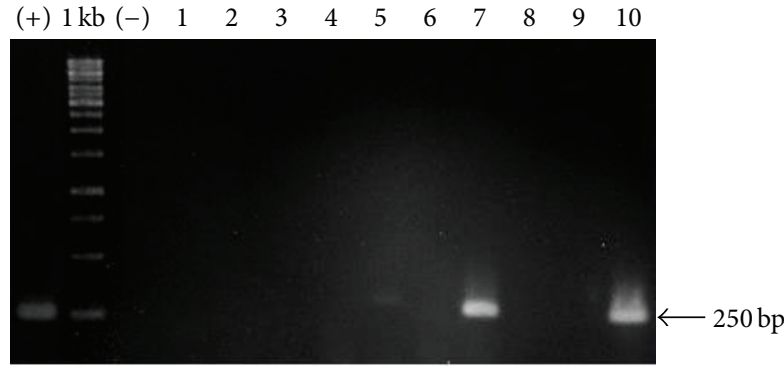

(a)

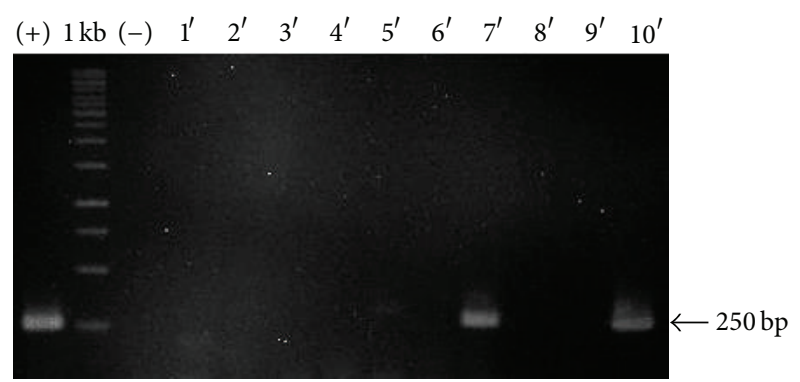

(b)

FIGURE 6: Electrophoresis result of PCR products of EBV specific gene using DNA purified by $\mathrm{Fe}_{3} \mathrm{O}_{4} / \mathrm{SiO}_{2}$ nanoparticles (a) and Dynabeads (b). (a) (+): PCR product of positive control pGEM-EBV, 1 Kb DNA ladder, (-): negative control, lane 1-10: PCR products using purified DNA of EBV from serum samples from number 1 to 10 by $\mathrm{Fe}_{3} \mathrm{O}_{4} / \mathrm{SiO}_{2}$ nanoparticles. (b) Lane $1^{\prime}-10^{\prime}$ : PCR products using purified DNA of EBV from serum samples from number 1 to 10 by Dynabeads.

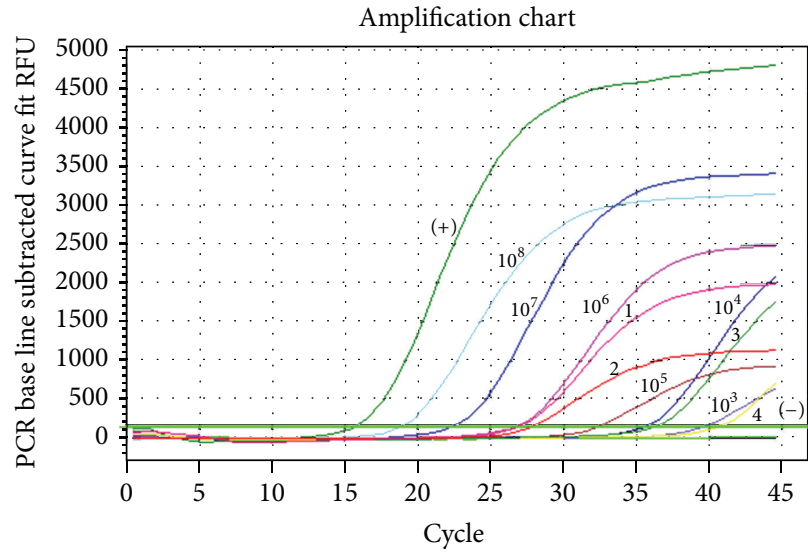

(a)

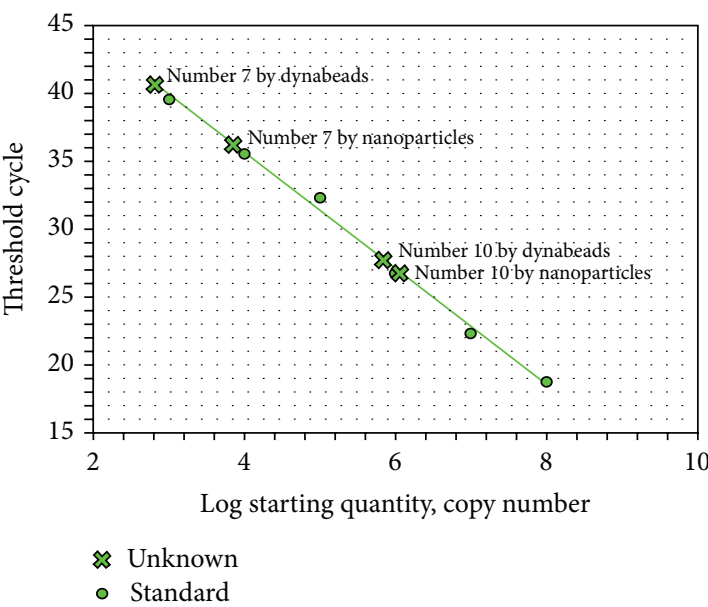

(b)

FIGURE 7: Real-time PCR for qualitative measurement EBV virus load using DNA templates purified by $\mathrm{Fe}_{3} \mathrm{O}_{4} / \mathrm{SiO}_{2}$ nanoparticles and Dynabeads. (a) Amplification chart of EBV-74 fragments specific for EBV from sample 7, sample 10, standards, and positive and negative controls. (+): PCR product of positive control pGEM-EBV-74 at $5 \times 10^{8}$ copies $/ \mathrm{mL},(-)$ negative controls, $10^{3}$ to $10^{8}$ copies $/ \mathrm{mL}$ were labeled next to each respective amplification curves of standards. (b) Linear regression line based on standards and featured with samples 7 and 10 purified by $\mathrm{Fe}_{3} \mathrm{O}_{4} / \mathrm{SiO}_{2}$ nanoparticles and Dynabeads $\left(R^{2}=0.996\right) .1,2,3$, and 4 were labeled next to amplification curves of samples number 7 by Nanoparticles, number 7 by Dynabeads, number 10 by Nanoparticles, and number 10 by Dynabeads, respectively.

PCR based on highly specific Taqman probe dually labeled with FAM at $5^{\prime}$-end and TAMRA at $3^{\prime}$-end was performed with samples 7 and 10 to quantify the EBV virus load. As shown in the amplification chart of Figure 7, the negative control had no amplification curve while the positive control had an amplification curve occurring earlier $\left(C_{t}=15.65\right)$. All standards together with samples 7 and 10 purified by both particles had amplification curves. The linear regression line of standards had $R^{2}=0.996$ value, indicating that the reliability of the qualitative measurement for EBV virus load was high. The concentration of EBV in sample 7 using DNA purified by $\mathrm{Fe}_{3} \mathrm{O}_{4} / \mathrm{SiO}_{2}$ nanoparticles $(=7.17 \times$ $10^{3}$ copies $/ \mathrm{mL}$ ), although this was much lower than that in sample $10\left(=1.18 \times 10^{6}\right.$ copies $\left./ \mathrm{mL}\right)$, but was not too low because it fell in the range of standards. Nanoparticles are therefore suitable for isolating DNA at such low virus concentration. The result in Table 1 indicates that higher concentrations of EBV (copies/mL) in both samples were measured with using $\mathrm{Fe}_{3} \mathrm{O}_{4} / \mathrm{SiO}_{2}$ nanoparticles to purify DNA compared to those with using Dynabeads. The increase in DNA isolation efficiency by $\mathrm{Fe}_{3} \mathrm{O}_{4} / \mathrm{SiO}_{2}$ nanoparticles is likely due to a larger total surface of silica-coated magnetic nanoparticles. During the process of DNA isolation, we have found that the time required for magnets to attract completely the Dynabeads from solution was much longer, about 2$3 \mathrm{~min}$, compared to $15-20 \mathrm{~s}$ for $\mathrm{Fe}_{3} \mathrm{O}_{4} / \mathrm{SiO}_{2}$ nanoparticles. This phenomenon is probably also due to the fact that $\mathrm{Fe}_{3} \mathrm{O}_{4} / \mathrm{SiO}_{2}$ nanoparticles have a larger total surface area compared to that of the Dynabeads.

\section{Conclusion}

Our study demonstrates that $\mathrm{Fe}_{3} \mathrm{O}_{4} / \mathrm{SiO}_{2}$ nanoparticles and the optimized buffers can isolate genomic DNA of two types 
of viruses, $\mathrm{HBV}$ and $\mathrm{EBV}$, for further PCR-based detection of the viruses in serum samples. The obtained primary data indicates that $\mathrm{Fe}_{3} \mathrm{O}_{4} / \mathrm{SiO}_{2}$ nanoparticles provided better sensitivity and were time saving in detection of $\mathrm{HBV}$ and EBV, compared to that of the commercialized silica-coated magnetic microparticles. Further experiments on nucleic acid isolation of other pathogenic viruses infected in blood using the $\mathrm{Fe}_{3} \mathrm{O}_{4} / \mathrm{SiO}_{2}$ nanoparticles are in progress.

\section{Conflict of Interests}

The authors declare no conflict of interests.

\section{Acknowledgments}

The authors would like to thank the Vietnam Ministry of Science and Technology (Project 2/2010/HD-NCCBUD) for financial support. They also thank Luu Manh Quynh of VNU University of Science, Vietnam, for technical assistance and Professor Simon Cutting of Royal Holloway University of London, UK, for critical reading of the paper.

\section{References}

[1] R. Boom, C. J. A. Sol, M. M. M. Salimans, C. L. Jansen, P. M. E. Wertheim-van Dillen, and J. van der Noordaa, "Rapid and simple method for purification of nucleic acids," Journal of Clinical Microbiology, vol. 28, no. 3, pp. 495-503, 1990.

[2] J.-I. Akutsu, Y. Tojo, O. Segawa et al., "Development of an integrated automation system with a magnetic bead-mediated nucleic acid purification device for genetic analysis and gene manipulation," Biotechnology and Bioengineering, vol. 86, no. 6 , pp. 667-671, 2004

[3] P. Ashtari, X. He, K. Wang, and P. Gong, "An efficient method for recovery of target ssDNA based on amino-modified silicacoated magnetic nanoparticles," Talanta, vol. 67, no. 3, pp. 548554,2005

[4] R. Caldarelli-Stefano, L. Vago, S. Bonetto, M. Nebuloni, and G. Costanzi, "Use of magnetic beads for tissue DNA extraction and IS6110 Mycobacterium tuberculosis PCR," Molecular Pathology, vol. 52, no. 3, pp. 158-160, 1999.

[5] D. van Baarle, E. Hovenkamp, M. J. Kersten, M. R. Klein, F. Miedema, and M. H. J. van Oers, "Direct Epstein-Barr virus (EBV) typing on peripheral blood mononuclear cells: no association between EBV type 2 infection or superinfection and the development of acquired immunodeficiency syndromerelated non-Hodgkin's lymphoma," Blood, vol. 93, no. 11, pp. 3949-3955, 1999.

[6] N. H. Hai, N. D. Phu, N. H. Luong et al., "Mechanism for sustainable magnetic nanoparticles under ambient conditions," Journal of the Korean Physical Society, vol. 52, no. 5, pp. 13271331, 2008.

[7] A. Abe, K. Inoue, T. Tanaka et al., "Quantitation of hepatitis B virus genomic DNA by real-time detection PCR," Journal of Clinical Microbiology, vol. 37, no. 9, pp. 2899-2903, 1999.

[8] P. T. Nghia, K. T. Nga, N. T. H. Loan et al., "Multiplex (RT)-PCR assay for detection of co-infection of HBV, HCV and HIV in blood samples," VNU Journal of Science, Natural Sciences and Technology, vol. 24, no. 2, supplement, pp. 377-383, 2008.
[9] H. G. M. Niesters, J. van Esser, E. Fries, K. C. Wolthers, J. Cornelissen, and A. D. M. E. Osterhaus, "Development of a real-time quantitative assay for detection of Epstein-Barr virus," Journal of Clinical Microbiology, vol. 38, no. 2, pp. 712-715, 2000.

[10] N. H. Luong, N. D. Phu, N. H. Hai, and N. T. D. Thuy, "Surface modification of $\mathrm{SiO}_{2}$-coated $\mathrm{FePt}$ nanoparticles with Amino Groups," e-Journal of Surface Science and Nanotechnology, vol. 9, pp. 536-538, 2011 

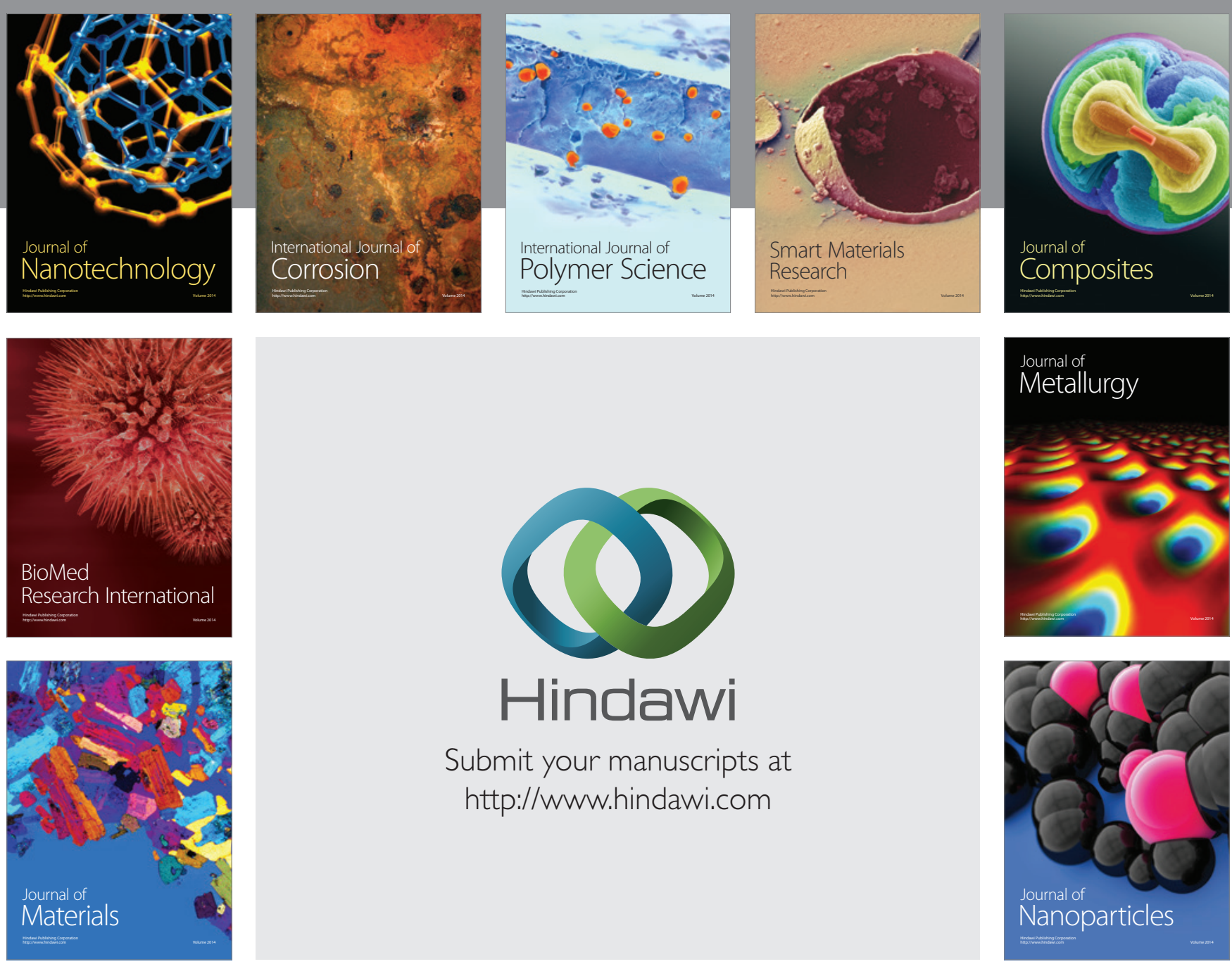

Submit your manuscripts at http://www.hindawi.com
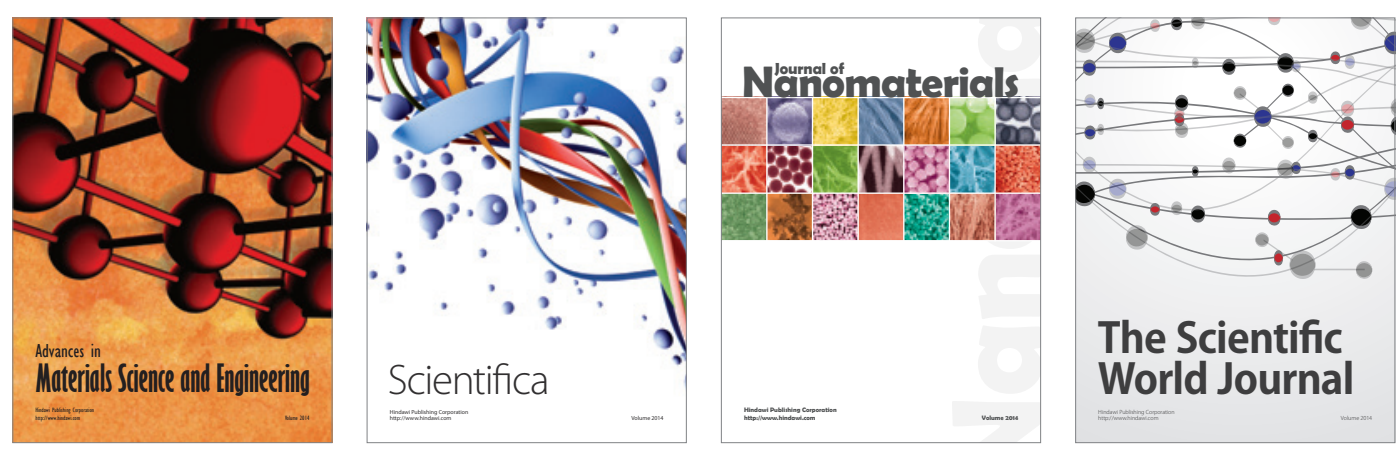

\section{The Scientific World Journal}
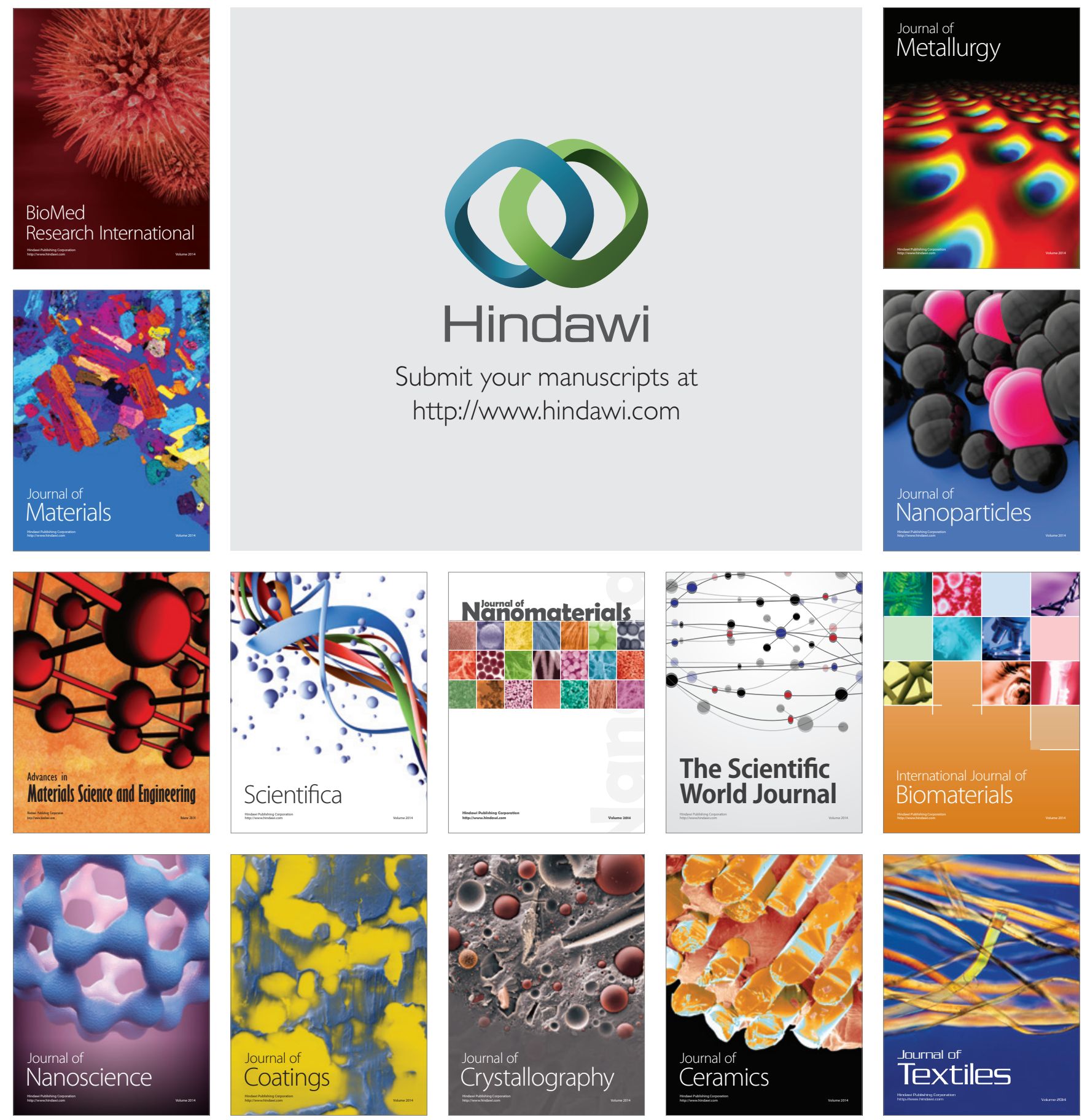